\title{
Initial growth and production of secondary metabolites in Basella alba leaves cultivated in a sandy textured soil with addition of organic and organo-mineral substrate
}

\author{
José Carlos Pina, Ademir Kleber Morbeck-de-Oliveira \& Rosemary Matias \\ Programa de Pós-Graduação em Meio Ambiente e Desenvolvimento Regional, Universidade Anhanguera-Uniderp, Rua \\ Alexandre Herculano, 1400, Campo Grande, Mato Grosso do Sul, Brazil.
}

Correspondence

AK. Morbeck-de-Oliveira

E-mail: akmorbeckoliveira@gmail.com

Received: 30 July 2021

Accepted: 24 November 2021

Published on-line: 22 January 2022

\section{Resumen}

Crecimiento inicial y producción de metabolitos secundarios en hojas de Basella alba cultivadas en un suelo de textura arenosa con adición de sustrato orgánico y organomineral

La especie Basella alba se conoce popularmente como bertalha india y se consume ampliamente en forma de ensaladas, por ejemplo. El objetivo de este estudio fue evaluar las etapas iniciales de crecimiento y la producción de metabolitos secundarios en diferentes sustratos. Transcurridos 90 días desde el inicio de la plantación (pleno sol), en suelo arenoso mezclado con diferentes sustratos, se determinó el efecto de los sustratos sobre el crecimiento y producción de metabolitos secundarios en las hojas. Los resultados indicaron que el tratamiento con la adición de $70 \%$ de vermicompost indujo el mayor crecimiento y la mejor concentración de compuestos fenólicos y flavonoides. Sin embargo, la mayoría de los tratamientos dieron como resultado la producción de heterósidos cardiotónicos, que pueden causar problemas de salud.

Palabras clave: Vermicompost; Verduras de hoja; Espinaca india; Heterósidos cardiotónicos; Flavonoides; Compuestos fenólicos.

\begin{abstract}
The species Basella alba is popularly known as Indian bertalha and is widely consumed in the form of salads, for example. Due to its potential for use, the objective of this study was to evaluate the initial stages of growth and the production of secondary metabolites in different substrates. After 90 days from the beginning of planting (full sun), in sandy soil mixed with different substrates, the effect of substrates on growth and the production of secondary metabolites in leaves was determined. The results indicated that the treatment with the addition of $70 \%$ of vermicompost induced the highest growth and the best concentration of phenolic and flavonoid compounds. However, most of the treatments resulted in the production of cardiotonic heterosides, which can cause health problems.
\end{abstract}

Key words: Vermicompost; Leafy vegetables; Indian spinach; Cardiotonic heterosides; Flavonoids; Phenolic compounds. 


\section{Introduction}

The species Basella alba L. (Basellaceae) originates in Southeast Asia and is popularly called Indian bertalha or spinach, and is widely consumed in the form of salads, stews, sweet bread and cakes, soufflés and green broths among other forms of preparation. It is a perennial herbaceous plant, vigorous, with thick leaves of light green color, being cultivated and commercialized in Brazil in the States of Amazonas, Pará and Rio de Janeiro (Kinupp \& Lorenzi 2014).

The plant has high levels of vitamins $\mathrm{A}, \mathrm{C}$ and B9, mineral salts (calcium, magnesium, iron and phosphorus) and amino acids such as arginine, leucine, isoleucine, lysine, threonine and tryptophan (Khare 2012) and according to Yen et al. (2001), the species has no toxicity and can be used as a vegetable.

It is a source of several compounds, such as saponins, carotenoids, polysaccharides, mucilages, organic acids, bioflavonoids, anthocyanins, tannins, triterpenes, terpene-free, steroids, alkaloids and pigments such as betacyanin (Deshmukh \& Gaikwad 2014, Tongco et al. 2015). According to Arya et al. (2021), the species has been used to treat problems with fungi, skin disorder, anemia and seizures, among other problems. Kumar et al. (2018) describes that the species have been used in traditional medicine system in India and widely consumed as a leafy vegetable.

It develops better in hot climate regions, where part of the leafy vegetables presents difficulty of growth. The ideal temperatures for its development are between 26 and $28{ }^{\circ} \mathrm{C}$, and the soil for cultivation must be light, fertile and with good organic matter content. From 60 days after the transplant of the seedlings, the collection can already be started, with its great regeneration power supporting countless cuts (MAPA 2010).

However, for the production of suitable plants, it is necessary to use substrates suitable for the plant development. A properly nourished plant has good growth, producing leaves and eye-catching roots, in addition to the characteristic compounds of the species. In this sense, the development of the root system has a direct influence on some characteristics of the species, such as drought resistance, efficiency in nutrient absorption and tolerance to soil pests attack, which affect final productivity (Primavesi 2017).
To increase productivity, organic and inorganic materials are often added to the soil, favoring their chemical, physical and biological characteristics and creating an environment suitable for the plants' development. However, it is also important to know how substrates affect, in addition to plant development, the production of secondary compounds. Czelusniak et al. (2012) highlight the importance of knowing which factors can influence the chemical composition of the species, such as edaphic and climatic ones, for example.

Therefore, it is relevant to identify raw materials that can be used as options for the production of substrates, enabling the reduction of costs and the increase in the producer's profitability. The objective of this study was to evaluate the development and production of secondary metabolites by $B$. alba cultivated in full sun on sandy soil with the addition of different substrates.

\section{Materials and methods}

\section{Place of cultivation}

The experiment was carried out at the Agricultural Campus of the Anhanguera-Uniderp University (2026'16.6”'S; 5432'14.5'W), Campo Grande, Mato Grosso do Sul, Brazil, from September to November 2018.

The altitude in the region is 665 masl and the climate, according to the Koppen-Geiger classification, is situated in the transition range between the humid mesothermic subtype (CFA) without draught or short draught and the tropical moist subtype (AW), with a rainy and hot season in summer and dry in winter (CPTEC-INPE, 2018). The mean temperature during the experiment was $27.5^{\circ} \mathrm{C}$ and the mean rainfall in the period was $196.2 \mathrm{~mm}$, with the highest rainfall frequency between October $5^{\text {th }}$ and November $2^{\text {nd }}(I N M E T$ 2018).

\section{Soils, substrates and treatments}

The soil used as the basis for the experiment was Quartzarenic Neosol (QN), with a sandy texture. The treatments were prepared with the addition of vermicompost (VC), a type of organic substrate; and, commercial substrate (CS), an organo-mineral substrate, in different proportions. Quartzarenic Neosol was collected in the Agrarian Campus, in an area of Cerrado (Savanna), at a depth of $0-20 \mathrm{~cm}$. After being collected, it was dried on pa- 


\begin{tabular}{lc}
\hline \multicolumn{1}{c}{ Parameters } & Values \\
\hline $\mathbf{P}\left(\mathbf{m g ~ d m}^{-3}\right)$ & 8.5 \\
$\mathbf{K}^{+}\left(\mathbf{m g ~ d m}^{-3}\right)$ & 34 \\
$\mathrm{Ca}^{++}\left(\mathbf{c m o l}^{+} \mathbf{~ d m}^{-3}\right)$ & 1.8 \\
$\mathbf{M g}^{++}\left(\mathbf{c m o l}^{+} \mathbf{~ d m}^{-3}\right)$ & 0.9 \\
$\mathbf{H}^{+}+\mathbf{A l}^{3+}\left(\mathbf{c m o l}^{+} \mathbf{~ d m}^{-3}\right)$ & 2.6 \\
Sum of bases $\left(\mathrm{cmol}^{+} \mathbf{~ d m}^{-3}\right)$ & 2.8 \\
Cation exchange capacity (cmol $\left.\mathbf{~ d m}^{-3}\right)$ & 5.4 \\
Saturation per base $(\mathbf{V} \%)$ & 50.9 \\
Organic matter $\left(\mathbf{g ~ d m}^{-3}\right)$ & 18.3 \\
pH $\mathbf{H}_{2} \mathrm{O}$ & 5.4 \\
\hline
\end{tabular}

Tabla 1. Atributos químicos del Neosol Cuarzorénico, Campo Grande, Mato Grosso do Sul, Brazil.

Table 1. Chemical attributes of the Quartzarenic Neosol, Campo Grande, Mato Grosso do Sul, Brazil.

per in a greenhouse, crumbled, sieved $(2 \mathrm{~mm}$ mesh) and analyzed using the method of Mehlich ${ }^{-1}$ ( $\mathrm{pH}$ in $\mathrm{H}_{2} \mathrm{O}, \mathrm{P}$ and $\left.\mathrm{K}^{+}\right)$and $\mathrm{KCl}(1 \mathrm{~N})\left(\mathrm{Ca}^{++}, \mathrm{Mg}^{++}\right.$ and $\mathrm{H}^{+}+\mathrm{Al}^{3+}$ ) (Table 1). Organic matter was analyzed using the colorimetric method (Teixeira et al. 2017).

The vermicompost, prepared with residues of bovine rumen under the action of the Red Californian earthworms (Eisenia foetida (Savigny, 1826)), was composted for 30 days and kept in the shade for 70 days. It has the following attributes: $\mathrm{pH}=7.0$; electrical conductivity $=1.23 \mathrm{mS} \mathrm{dm}^{-1}$; $\mathrm{P}=260 \mathrm{mg} \cdot \mathrm{kg}^{-1}, \mathrm{~K}^{+}=600 \mathrm{Mg}^{++} \mathrm{kg}^{-1} ; \mathrm{Ca}^{++}=25 \mathrm{cmol}^{+}$ $\mathrm{dm}^{-3} ; \mathrm{H}^{+}=6.54 \mathrm{cmol}^{+} \mathrm{dm}^{-3} ;$ density $=0.39 \mathrm{~g} \mathrm{~cm}^{-3}$; organic matter $=12.94 \%$. The commercial substrate, prepared with ash, organic compound, Pinus powder and vermiculite, has $\mathrm{pH}=7.3$; density $=0,45 \mathrm{gcm}^{-3}$; water retention capacity $=165 \%$; electrical conductivity $=1.5 \mathrm{mS} \mathrm{dm}{ }^{-1}$; moisture $=$ $25 \%$ (product information).

After the proportions were determined for each substrate, the mixtures of the components were made and homogenization was performed, and the following treatments $(\mathrm{T})$ were assembled: $\mathrm{T} 1=\mathrm{CS}$ $30 \%+70 \%$ QN; T2 $=$ VC $30 \%+70 \%$ QN; T3 $=\mathrm{CS}$ $70 \%+30 \%$ QN; and, $\mathrm{T} 4=\mathrm{VC} 70 \%+30 \% \mathrm{QN}$. The substrates were then packed in culture bags $(20$ $\mathrm{cm}$ wide $\times 30 \mathrm{~cm}$ high) with a volumetric capacity of $3.4 \mathrm{~L}$.

\section{Cutting collection}

Following indications from Campos et al. (2010), seedlings (herbaceous cuttings) of different matrix plants (10) were collected, cultivated by multipliers of the program "Horta em Casa" of Mokiti Okada Foundation, Campo Grande, in September 2018. The botanical material was wrapped in water-soaked newspapers, packed in plastic bags and transported to the Research Laboratory, Agrarian Campus.

The cuttings were selected and the basal ones without leaves were chosen, standardized with approximately $15 \mathrm{~cm}$ length, 6 to $8 \mathrm{~mm}$ of collar and three buds. After the selection, the cutting was made in cultivation bags, one cutting per container, burying one knot. After two days of acclimation (greenhouse with 20\% luminosity), the planting bags were transferred to the experiment area (in full sunlight), with average daily maximum radiation of $2319.41 \mathrm{KJ} \mathrm{m}^{-2}$, from September to November 2018 (INMET, 2018), the maximum daily peak of the 90 days regarding the duration of the experiment was observed and the mean was calculated.

\section{Evaluation of plants growth}

After 90 days of cultivation in full sunlight the height of the aerial part of the plants was evaluated (stem base of the seedling to the apex of the meristematic system, in $\mathrm{cm}$, with ruler).

After this procedure, the plants were collected and divided into root and aerial part, being weighed in analytical balance $( \pm 0,0001 \mathrm{~g})$ (individual fresh mass was determined in grams).

\section{Obtaining the plant extracts}

The leaves collected was stored in numbered paper bags and placed in a forced ventilation oven at $65 \pm 2{ }^{\circ} \mathrm{C}$ for dehydration. The dry material was crushed and used for the preparation of the methanolic extract, using $20 \mathrm{~g}$ of dry leaf dust from the different treatments in $100 \mathrm{~mL}$ of methanol $(99,5 \%)$. The extraction initially occurred in ultrasound equipment (UNIDQUE ${ }^{\circledR}$, 1450) for 60 minutes, followed by 48 hours of extraction by static maceration (Oliveira et al. 2013). Subsequently, the resulting liquid was filtered on filter paper, using a glass funnel and then concentrated by rotary evaporator, dried on a desiccator, under vacuum, with the crude extract submitted to preliminary phytochemical analysis. In order to confirm the presence of some secondary metabolite classes, tests were repeated with aqueous extract, obtained by decoction of $2.0 \mathrm{~g}$ of leaves dust and $10.0 \mathrm{~mL}$ of distilled water for 3 minutes.

\section{Phytochemical analysis}

Phytochemical tests were performed using the 
adapted method of Matos (2009) and Simões et al. (2017), with the extracts obtained. The analyses were performed in triplicate, and the results were compared with the control sample, observing changes in colour and precipitation. Changes in colour were classified as partial $( \pm ; 10 \%)$, low (+; $25 \%)$, moderate $(++; 50 \%)$, medium $(++ \pm ; 75 \%)$, high intensity $(+++; 100 \%)$, or negative $(-; 0)$ (Fontoura et al. 2015). The tests with precipitate formation (phenolic compounds and tannins) were carried out in graduated tubes, and the results were classified as partial intensity $(<0.2 \mathrm{~cm})$, low $(0.21$ to $0.5 \mathrm{~cm})$, moderate $(0.51$ to $0.7 \mathrm{~cm})$, and high intensity ( 0.71 to $1.0 \mathrm{~cm}$ ) (Fontoura et al. 2015).

\section{Frequency (Intensity)}

The characterization analyzes were of phenolic compounds (precipitation reaction with ferric chloride), naphthoquinone (acid/base reaction), flavonoids (Cyanidin/Shinoda and sulfuric acid The compounds flavonics form oxonium salts), tannins (reaction with iron salts, protein precipitation), coumarins ( $\mathrm{KOH} \mathrm{5 \%} \mathrm{and} \mathrm{ultraviolet} \mathrm{light),}$ triterpenes, steroids and saponins (LiebermannBurchard reaction), cyanogenic heterosides (Guignard test) and cardioactive heterosides (Liebermann-Burchard reaction [steroidal nucleus reaction] and Baljet and Kedde reaction [lactonic ring]). For confirmation of the presence of triterpenes and steroids, the methanolic extract was hydrolyzed with a potassium hydroxide solution $(0.5$ mol L $\mathrm{L}^{-1}$ ) and submitted to reflux for 1 hour. The extracts were extracted with ethyl ether and in sequence, submitted to Liebermann-Burchard reaction. To confirm the presence or absence of saponins, the adapted surface action test of was used Athayde et al. (2017). After energetic agita- tion of the filtered extract in test tube (20 seconds), followed by rest (15 minutes), foam formation (height) was observed, which in the case of the positive test does not disappear with the addition of acid.

\section{Quantification of phenolic compounds and flavonoids}

The extracts were used to quantify the total phenols ( $\mathrm{mg}$ of gallic acid equivalents per $\mathrm{g}$ of extract - mg EAG $/ \mathrm{g}^{-1}$ ), determined by the Folin-Ciocalteu method, with gallic acid (10 to $\left.350 \mathrm{mg} \mathrm{mL}^{-1}\right)$ as the standard $\left(\mathrm{y}=0.02 \mathrm{x}+0.042 ; \mathrm{r}^{2}=0.9999\right)$ (Sousa et al. 2007). The total flavonoids content (equivalent $\mathrm{mg}$ of quercetin per $\mathrm{g}$ of extract $-\mathrm{mg} \mathrm{EQ} / \mathrm{g}^{-1}$ ) was evaluated by the aluminium chloride method and as standard, quercetin (6 to $20 \mu \mathrm{g} \mathrm{mL}^{-1}$ ) to construct the calibration curve $(\mathrm{y}=0.042 \mathrm{x}+$ $0.0081 ; \mathrm{r}^{2}=0.9999$ ) (Peixoto-Sobrinho et al. 2008).

\section{Results}

\section{Substrates}

The addition of vermicompost and commercial substrate to sandy soil resulted in an improvement in the nutritional and chemical characteristics of the base soil (Table 1). There was an increase in nutrients (phosphorus, potassium, calcium and magnesium), organic matter and cation exchange capacity, in addition to the reduction of potential acidity and increase in $\mathrm{pH}$, tending to neutrality (Table 2).

By evaluating the substrates, in terms of higher nutrient concentration, CEC, organic matter, in addition to lower potential acidity, T3 (70\% CS) stand out in all the parameters (Table 2).

\begin{tabular}{|c|c|c|c|c|c|}
\hline & T1 CS30\%+QN70\% & T2 VC30\%+QN70\% & T3 CS70\%+QN30\% & T4 VC70\%+QN30\% & LSD (1\%) \\
\hline$P\left(\mathrm{mg} \mathrm{dm}^{-3}\right)$ & $29.1 \mathrm{~b}$ & $29.8 b$ & $54.6 \mathrm{a}$ & $58.2 \mathrm{a}$ & 9.4 \\
\hline $\mathrm{K}^{+}\left(\mathrm{mg} \mathrm{dm}^{-3}\right)$ & $106.8 \mathrm{~b}$ & $75.0 \mathrm{c}$ & $210.0 \mathrm{a}$ & $89.6 \mathrm{c}$ & 56.1 \\
\hline $\mathrm{Ca}^{++}\left(\mathrm{cmol}^{+} \mathrm{dm}^{-3}\right)$ & $5.5 \mathrm{~b}$ & $4.6 \mathrm{~b}$ & $7.3 \mathrm{a}$ & $7.5 \mathrm{a}$ & 1.5 \\
\hline $\mathrm{Mg}^{++}\left(\mathrm{cmol}^{+} \mathrm{dm}^{-3}\right)$ & $2.8 \mathrm{~b}$ & $1.8 \mathrm{c}$ & $4.0 \mathrm{a}$ & $1.3 \mathrm{c}$ & 1.5 \\
\hline $\mathrm{H}^{+}+\mathrm{Al}^{3+}\left(\mathrm{cmol}^{+} \mathrm{dm}^{-3}\right)$ & $0.85 a$ & $1.49 \mathrm{~b}$ & $0.89 a$ & $2.24 \mathrm{c}$ & 0.25 \\
\hline $\mathrm{CEC}\left(\mathrm{cmol}^{+} \mathrm{dm}^{-3}\right)$ & $9.6 \mathrm{c}$ & $9.4 \mathrm{c}$ & $12.8 \mathrm{a}$ & $11.3 \mathrm{~b}$ & 1.8 \\
\hline $\mathrm{OM}\left(\mathrm{g} \mathrm{dm}^{-3}\right)$ & $27.8 \mathrm{~b}$ & $28.8 \mathrm{~b}$ & $40.6 \mathrm{a}$ & $42.8 \mathrm{a}$ & 4.5 \\
\hline $\mathrm{pH}\left(\mathrm{H}_{2} \mathrm{O}\right)$ & $6,9 a b$ & $6.7 \mathrm{ab}$ & $7.2 \mathrm{a}$ & $6.4 \mathrm{~b}$ & 0.54 \\
\hline
\end{tabular}

Tabla 2. Características edáficas de los sustratos utilizados para el cultivo de Basella alba a pleno sol. Acidez potencial $\left(\mathrm{H}^{+}+\mathrm{Al}^{3+}\right)$; capacidad de intercambio catiónico (CEC); materia orgánica (OM); LSD (diferencia mínima significativa). Neosol cuarzarénico (QN); vermicompost (VC); sustrato comercial (CS). *Las medias seguidas de letras minúsculas iguales en las columnas no difieren entre sí, prueba de Tukey al $1 \%$.

Table 2. Edaphic characteristics of the substrates used for the cultivation of Basella alba in full sunlight. Potential acidity $\left(\mathrm{H}^{+}+\mathrm{Al}^{3+}\right)$; cationic exchange capacity (CEC); organic matter (OM); LSD (least significant difference). Quartzarenic neosol (QN); vermicompost (VC); commercial substrate (CS). *Means followed by equal lowercase letters in columns do not differ among themselves, Tukey test at $1 \%$. 


\section{Growth}

The results obtained indicated that $\mathrm{T} 4(70 \% \mathrm{VC})$ presented the greatest growth in height and accumulation of fresh matter in the aerial part (Table $3)$.

\begin{tabular}{ccccc}
\hline Treatments & Height & Root & Aerial part & $\begin{array}{c}\text { Total } \\
\text { fresh weight }\end{array}$ \\
\hline T1 (CS 30\%+QN 70\%) & $25.0 \mathrm{~b}$ & $3.0 \mathrm{a}$ & $67.2 \mathrm{c}$ & $74.3 \mathrm{c}$ \\
T2 (VC 30\%+QN 70\%) & $29.6 \mathrm{~b}$ & $3.2 \mathrm{a}$ & $74.7 \mathrm{c}$ & $77.9 \mathrm{c}$ \\
T3 (CS 70\%+QN 30\%) & $113.1 \mathrm{a}$ & $2.7 \mathrm{a}$ & $118.9 \mathrm{~b}$ & $121.5 \mathrm{~b}$ \\
T4 (VC 70\%+QN 30\%) & $105.2 \mathrm{a}$ & $3.0 \mathrm{a}$ & $190.9 \mathrm{a}$ & $193.9 \mathrm{a}$ \\
\hline
\end{tabular}

Tabla 3. Influencia de diferentes tipos de sustratos en el crecimiento de plantas de Basella alba a pleno sol. Altura (cm), peso fresco de la raíz $(\mathrm{g})$, parte aérea $(\mathrm{g})$ y peso fresco total $(\mathrm{g})$. Medias seguidas de minúsculas iguales en las columnas no difieren entre sí, prueba de Tukey al 1\%.

Table 3. Influence of different types of substrates on the growth of Basella alba plants under full sunlight. Height $(\mathrm{cm})$, root fresh weight $(\mathrm{g})$, aerial part $(\mathrm{g})$ and total fresh weight $(\mathrm{g}) .{ }^{*}$ Means followed by equal lowercase letters in columns do not differ among themselves, Tukey test at $1 \%$.

\section{Secondary metabolites and total phenols and flavonoids contents}

The results indicated that the cultivation of bertalha on different substrates did not affect the diversity of secondary metabolites, with all treatments presenting nine classes. However, different treatments affect the frequency of compounds (\%) (Fig. 1).

The phenolic compounds (T2 and T4), tannins (all treatments), flavonoids ( $\mathrm{T} 1, \mathrm{~T} 2$ and $\mathrm{T} 4$ ), saponins ( $\mathrm{T} 1$ and $\mathrm{T} 2$ ), steroids ( $\mathrm{T} 1$ and $\mathrm{T} 3$ ), triterpenes (T1 and T3) and cardiotonic heterosides (all treatments) were highlighted with positive intensity, strongly positive and high intensity. Free coumarins were identified with weakly positive or partial positive intensity and free anthraquinones, weakly positive intensity only in T4 (Fig. 1).

Regarding the quantification of compounds,

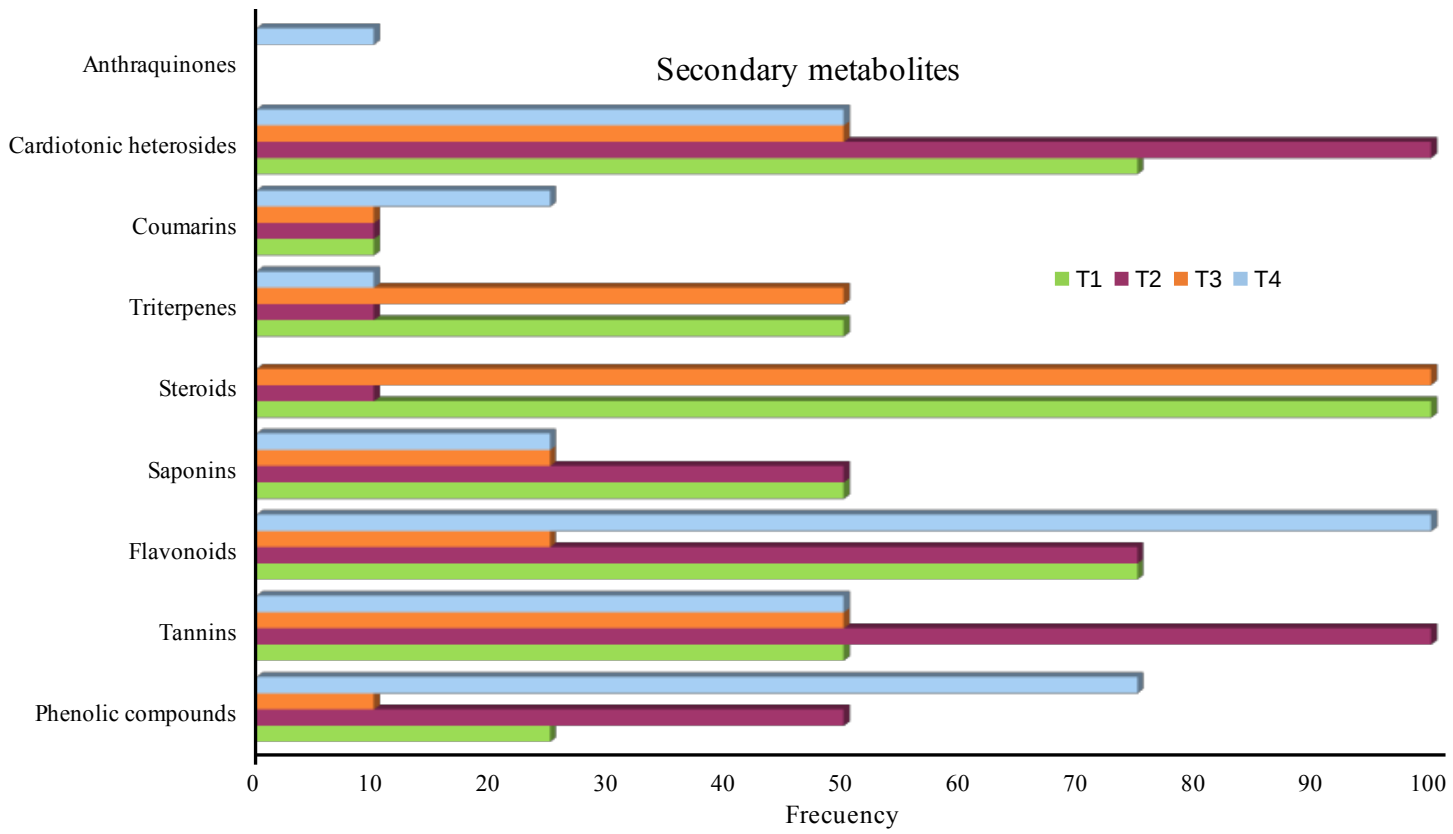

Figura 1. Frecuencia de metabolitos secundarios encontrados en hojas de Basella alba cultivadas a pleno sol utilizando diferentes sustratos. $\mathrm{T} 1=\mathrm{CS} 30 \%+\mathrm{QN} 70 \% ; \mathrm{T} 2=\mathrm{VC} 30 \%+\mathrm{QN} 70 \% ; \mathrm{T} 3=\mathrm{CS} 70 \%+\mathrm{QN} 30 \% ; \mathrm{T} 4=\mathrm{VC} 70 \%+\mathrm{QN} 30 \%$.

Figure 1. Frequency of secondary metabolites found in leaves of Basella alba grown in full sun using different substrates. T1 $=\mathrm{CS} 30 \%+$ $\mathrm{QN} 70 \% ; \mathrm{T} 2=\mathrm{VC} 30 \%+\mathrm{QN} 70 \% ; \mathrm{T} 3=\mathrm{CS} 70 \%+\mathrm{QN} 30 \% ; \mathrm{T} 4=\mathrm{VC} 70 \%+\mathrm{QN} 30 \%$.

\begin{tabular}{ccccc}
\hline & T1 (CS30\%+QN70\%) & T2 (VC30\%+QN70\%) & T3 (CS70\%+QN30\%) & T4 (VC70\%+QN30\%) \\
\hline $\begin{array}{c}\text { Phenolic compounds } \\
\left.\text { (mg EAG } / \mathbf{g}^{-1}\right)\end{array}$ & $181.0 \mathrm{~b}$ & $209.1 \mathrm{a}$ & $169.5 \mathrm{c}$ & $212.8 \mathrm{a}$ \\
$\begin{array}{c}\text { Flavonoids } \\
\text { (mg EQ/g }^{-1} \text { ) }\end{array}$ & $120.3 \mathrm{~b}$ & $128.8 \mathrm{~b}$ & $105.7 \mathrm{c}$ & $156.5 \mathrm{a}$ \\
\hline
\end{tabular}

Tabla 4. Cuantificación de compuestos fenólicos $\left(\mathrm{mg}\right.$ EAG $\left./ \mathrm{g}^{-1}\right)$ y flavonoides $\left(\mathrm{mg} \mathrm{EQ} / \mathrm{g}^{-1}\right)$ encontrados en hojas de plantas de Basella alba cultivadas a pleno sol, sobre diferentes sustratos. *Las medias seguidas de letras minúsculas iguales en las columnas no difieren entre sí, prueba de Tukey al 1\%.

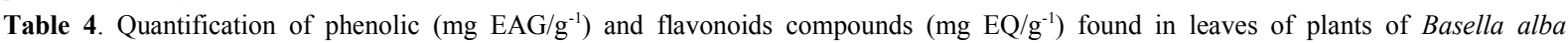
cultivated in full sun, on different substrates. *Means followed by equal lowercase letters in columns do not differ among themselves, Tukey test at $1 \%$. 
the results of phenolic and flavonoid compounds indicated that $\mathrm{T} 4(70 \% \mathrm{VC})$ presented the highest values, followed by T2 $(30 \% \mathrm{VC})$ (Table 4$)$.

\section{Discussion}

The best plant development of the species occurred in $\mathrm{T} 4(70 \% \mathrm{VC})$, followed by $\mathrm{T} 3(70 \%$ $\mathrm{CS})$. However, the substrate with the best chemical and organic characteristics was T3, indicating that not only the content of macronutrients or quantity of organic matter interfered in the plant development, with the substrate or micronutrients structure, which may be factors that provided the best development of the plants in T4. According to Passos et al. (2007), the type of fertilization has a great influence on growth; however, the higher values of some nutrients or organic matter do not always mean higher productivity.

This assumption is confirmed by information from Fernandes et al. (2018), who indicate that the micronutrient concentrations found may also interfere with the seedlings' growth, in addition to the texture of the substrate. On the other hand, the $\mathrm{pH}$ range 6.4-7.2 obtained for all treatments is the most favorable for plant growth, since the availability of some nutrients is maximum (macronutrients) and not limiting for others (micronutrients). This result indicates that $\mathrm{pH}$ would not be a limiting element for plants in different treatments.

Regarding substrate characteristics, the vermicompost produces significant improvements in crop yield and applications of this material, incombination with other substrates, allow better concentration and absorption of nutrients, besides reducing nitrogen loss from the soil by volatilization. It is a type of rich substrate, mainly in nitrogen, calcium, phosphorus, magnesium and potassium, with excellent cation exchange capacity and high organic matter content (Bayer \& Mielniczuk 2008, Primavesi 2017). Furthermore, the use of ruminal residue, by means of vermicomposting, may solve in part some problems generated with waste discarded, in favor of the sustainability of production, a viable alternative in terms of environmental preservation, resulting in a significant reduction in the application of chemical fertilizers.

In addition to these factors, the vermicompost provides a greater amount of water in the substrate, providing better growth conditions for the species, in addition to positively affecting the par- ticle aggregation. Bayer \& Mielniczuk (2008) stated that the effect of organic matter on aggregation indirectly influences other physical properties, such as density, porosity, retention capacity and water infiltration, among others, which are fundamental to productive capacity. Thus, the improvement of the substrate physical characteristics in $\mathrm{T} 4(70 \% \mathrm{VC})$ resulted in better plant growth, although $\mathrm{T} 4$ did not present the best chemical parameters.

However, due to the soil characteristics, of sandy texture and poor in nutrients and organic matter, a greater volume of this compound is necessary, since the addition of $30 \%$ of the vermicompost was not sufficient for the plants' good growth, despite its good quality. Soils with a sandy texture can often limit the development of the plants due to water restriction and nutrient diffusion, a factor that may have happened with treatments with a lower amount of organic matter (T1-30\% CS and $\mathrm{T} 2-30 \% \mathrm{VC}$ ).

However, the root system of all treatments was similar, with differences occurring in the aerial part. It can be assumed that the physical and chemical characteristics of the substrate were efficient for root growth, but a limiting factor for the aerial part. This result can be related to the adequate amount of phosphorus in the substrates, of great importance in rooting (Santos et al. 2011), since T3 (70\% CS) and T4 (70\% VC), with better growth, present the highest values, which may have interfered with the final yield of the plant.

Besides this factor, substrates with low water retention capacity reduce the amount of phosphorus absorbed by the plants due to lower diffusion rate, leading to a restricted growth. Costa et al. (2006), working with diffusive flow due to different phosphorus doses and soil moisture, concluded that this element is influenced by moisture, with higher water levels being more efficient, which may have occurred in T3 (70\% CS) and T4 (70\% VC). In this sense, Pina et al. (2018), evaluating the initial growth of Moringa oleifera Lam. in different substrates, observed that the addition of $40 \%$ of vermicompost to the base soil resulted in better growth of the aerial part and root system, in relation to the smaller addition of this compound, a result similar to that obtained by this experiment.

The commercial substrate has in its composition, organic compound and Pinus powder and, 
vermiculite, considered excellent organic soil conditioners, improving its porosity and the rooting of the plant, besides resulting in the immediate release of nutrients and later, through the decomposition of the organic compound. On the other hand, vermiculite, when added to the sandy soil, increases its aeration and water retention capacity, in addition to correcting its acidity, because it has a neutral pH. Boene et al. (2013) confirmed the effectiveness of this compound by evaluating the production of seedlings of Sebastiania commersoniana (Baillon) Smith and Downs. However, the characteristics of the commercial substrate affect species differently, since they may have different chemical-physical requirements in their initial phase of growth.

Thus, despite the commercial substrate providing good development for the $B$. alba plants, the vermicompost was superior in the process due to its specific characteristics. The differences in growth have shown that a large volume of organic matter is necessary to induce the best development of the species, when in sandy and acid texture soils. The organic matter, when added to the soil, changes its characteristics, allowing greater water retention and continued nutrient release, as well as improving its physical structure and reducing the $\mathrm{pH}$ and thermal oscillations, for example. According to Kämpf (2005), the physical and chemical properties of the substrates are influenced by the type of compound and availability of nutrients, interfering in the seedling development, which can be observed in the final result of the experiment.

\section{Secondary metabolites and total phenols and flavonoids contents}

The results indicated that despite the differences in substrates, the same secondary metabolites occurred in all the treatments. However, their intensity was distinct, demonstrating that the different types of substrates interfered in the synthesis process. According to Gobbo-Neto \& Lopes (2007), and Morais (2009), the production of secondary metabolites by the plant occurs as a function of plant $\mathrm{x}$ environment interaction, in response to abiotic and biotic factors, which explains the different intensities found.

In relation to the metabolites found, Tongco et al. (2015), who evaluated the extracts of leaves of B. alba cultivated in the Philippines, also identified metabolites such as alkaloids, diterpenes, phenols, flavonoids, cardiac glycosides, saponins and tannins, similar results to those found by this paper. Arya et al. (2021), with cultivation of the species in India, cited alkaloids, glycosides, tannins, flavonoids, poly phenols, and saponins. Adenegan-Alakinde \& Ojo (2018), south-western Nigeria, phenols, alkaloids, tannins, anthraquinones, flavonoids and saponins.

This information shows that despite the different cultivation regions, the species has similar metabolite classes. Gobbo-Neto \& Lopes (2007) and Morais (2009) write that many allelochemicals represent adaptive traits of the species and therefore are found in different regions and types of cultivation.

The results also indicate that the presence of anthraquinones and free coumarins is little expressive in all the treatments. The production of these metabolite classes in B. alba is not common, according to the sources researched (Suganthi \& Tamilarasi 2015, Tongco et al. 2015, Adegoke \& Ojo 2017, Aboshi et al. 2018, Revathi \& Sudha 2018 and Arya et al. 2021). However, under certain environmental conditions, their production may occur, in a small intensity, as observed in this paper and also reported by Adenegan-Alakinde \& Ojo (2018), in Nigeria.

On the other hand, tannins and cardiotonic heterosides stand out in all the treatments. But no pattern was observed in their production, a factor probably related to the chemical composition of the substrates and their physical structure. In popular medicine, traditionally, plants with the presence of tannins have high therapeutic potential. Their main applications are the empirical use in the healing of cutaneous wounds of ulcers and injuries and their pharmacological action is due to the richness of condensed tannins (Meira et al. 2013). In addition to the healing action, they also have anti-inflammatory, antimicrobial and antioxidant activities (Minatel et al. 2010), among other actions. On the other hand, their presence may affect the palatability of leaves and thus be a factor to restrict vegetable consumption, when high intensity is found.

Cardiotonic heterosides are a class of metabolites found in the species, for example, by Tongco et al. (2015) in leaves of specimens cultivated in Los Baños, Philippines, Revathi \& Sudha (2018), in collections performed in Salem, India. Pina et al. (2018) recommend caution when consuming plants with higher heterosides due to the risks associated with this class. According to Robbers 
et al. (2007), cardioactive drugs have in their composition cardiotonic heterosides, compounds that act directly in the myocardium, being used mainly in the treatment of congestive heart failure. However, the concentration capable of producing toxic effects is only twice as high as the therapeutic concentration, causing, for example, fatigue, nightmares and personality changes and in more serious cases, which can lead to death.

The triterpenes (terpenoids) stood out in T1 (30\% CS) and $\mathrm{T} 3(70 \% \mathrm{CS})$ and were already cited in leaves of B. alba by Tongco et al. (2015). This class has diuretic action (Ye et al. 2000) and antidiabetic action, also acting on the reduction of blood glucose (Alqahtani et al. 2013) and in the treatment of hepatitis (Cheng et al. 2011), among other actions. Terpenes are also toxins and foraging inhibitors for many insects and herbivorous mammals, playing important defense functions (Kortbeek et al. 2019).

The steroids, a type of phytosterol with higher intensity in T1 (30\% CS) and T3 (70\% CS), were also cited in plants of $B$. alba collected in India, by Suganthi \& Tamilarasi (2015), and Revathi \& Sudha (2018). In human health, this class has been used for therapeutic purposes for the treatment of cardiovascular diseases, in addition to contributing to the attenuation of breast, prostate, liver, lung, stomach and ovary cancer, among other effects (Ramprasath \& Awad 2015).

The saponins, found in higher intensity in $\mathrm{T} 1$ $(30 \% \mathrm{CS})$ and $\mathrm{T} 2(30 \% \mathrm{VC})$, are cited for B. alba by Tongco et al. (2015), Suganthi \& Tamilarasi (2015), Adegoke \& Ojo (2017), AdeneganAlakinde \& Ojo (2018), Revathi \& Sudha (2018), and Arya et al. (2021). They are compounds that dissolve in water resulting in sparkling solutions due to their tense action, having anti-helminthic and antifungal activity, for example (Simons et al. 2017). However, due to their hemolytic action, the treatments that produced a strongly positive intensity or high intensity would not be indicated for a regular human consumption.

It is interesting to point out that treatments with lower organic matter concentration presented higher intensities (positive, strongly positive and high intensity) of certain metabolic classes (T1$30 \% \mathrm{CS}=6$ metabolites; $\mathrm{T} 2-30 \% \mathrm{VC}=5$ metabolites). On the other hand, there was less intensity in metabolite classes when the substrate had a higher concentration of organic matter (T3-70\% $\mathrm{CS}=4$ metabolites; $\mathrm{T} 4-70 \% \mathrm{VC}=3$ metabolites), which may indicate that this element interferes with the intensity of these compounds. According to Gobbo-Neto \& Lopes (2007), the metabolites can be a strategy of plant defense and when the environment is not the most adequate, there is a change in their synthesis.

Regarding the quantification of metabolites, phenolic and flavonoid compounds stood out in $\mathrm{T} 4(70 \% \mathrm{VC})$, with higher value, followed by $\mathrm{T} 2$ $(30 \% \mathrm{VC})$, both with addition of vermicompost. Thus, the substrate with the highest vegetative growth (T4) also produced the highest concentrations of phenolic and flavonoid compounds, known as being a potential source of natural antioxidants (Sousa et al. 2007). Among the phenolic compounds flavonoids stand out, which have several biological activities, with antiinflammatory, antiviral, antibacterial and antiallergic action, associated with the prevention of chronic diseases, such as cancer and cardiovascular diseases, for example (King \& Young 1999).

Phenolic compounds have a great chemical diversity, allowing them to perform a variety of functions. For example, tannins, lignin, flavonoids and some simple phenolic compounds serve as defenses against herbivores and pathogens. Kumar et al. (2018) in an identification and characterization work of bioactive phenolic constituents, identified hydroxy-benzoic acids, hydroxy-cinnamic acids and flavones groups from the aqueous stem extracts of $B$. alba cultivated in India. Other researchers (Suganthi \& Tamilarasi 2015, Adegoke \& Ojo 2017, Aboshi et al. 2018, Adenegan-Alakinde \& Ojo 2018 and Jayswal et al. 2019) also identified flavonoids in B. alba; however, with values lower than those of this work, which shows that the type of treatment, geographical location and environmental conditions favored the production of this polyphenol. On the other hand, Arya et al. (2021) found higher values of phenolic compounds and flavonoids; however, the authors did not mention how the plants were cultivated.

One factor to be remembered is the influence of light on the production of secondary metabolites, as higher levels of radiation and the stress resulting from this environment interfere in the production of secondary compounds. For this reason, light is a basic physical factor essential to the development and bioactive secondary metabolite production. In this work, the growing conditions, under full sun, in a tropical region, probably inter- 
fered in the results obtained. For example, Lattanzio (2013) and Chalker-Scott \& Fuchigami (2018) write that plants increase the concentration of phenolic compounds and flavonoids when in greater light, as a defense strategy, to protect themselves from excess radiation. Thus, the cultivation of bertalha under shading conditions and with the same substrates would probably produce different results from those found in this work.

\section{Conclusions}

The species develops better, when in soils with a sandy texture, on substrates with a higher concentration of organic matter.

Although the T3 substrate (70\% CS) presented the highest nutritional values, the best vegetative development occurred in T4 $(70 \% \mathrm{VC})$, which also produced the highest amounts of phenolic and flavonoid compounds.

Most of the treatments presented an expressive amount of cardiotonic heterosides and substrates with a higher amount of organic matter produced less intensity of this class of metabolites.

In general, the continuous intake of $B$. alba should be cautious, and studies on clinical effects are necessary to standardize consumption without risk to human health, especially in patients with a history of heart failure.

\section{References}

Aboshi T, Ishiguri S, Shiono Y \& Murayama T. 2018. Flavonoid glycosides in Malabar spinach Basella alba inhibit the growth of Spodoptera litura larvae. Bioscience, Biotechnology, and Biochemistry 82(1): 9-14. https://doi.org/10.1080/09168451.2017.14063 01

Adegoke GO \& Ojo OA. 2017. Phytochemical, antioxidant and antimicrobial activities in the leaf, stem and fruit fractions of Basella alba and Basella rubra. Plant 5(5): 73-79. https://doi.org/10.11648/jplant. 20170505.11

Adenegan-Alakinde TA \& Ojo FM. 2018. Phytochemical and antioxidant properties of forms of Basella. International Journal of Vegetable Science 25(5): 431440. https://doi.org/10.1080/19315260.2018.15248 $\underline{08}$

Alqahtani A, Hamid K, Kam A, Wong KH, Abdelhaj Z, Razmovski-Naumovski V, . . Li GQ. 2013. The pentacyclic triterpenoids in herbal medicines and their pharmacological activities in diabetes and diabetic. Current Medicinal Chemistry 20(7): 908-931. https:// doi.org/10.2174/092986713805219082

Arya H, Mohan C, Pandey S, Verama M \& Kumar V. 2021. Phytochemical screening of Basella alba leaves extracts and evaluate its efficacy on sun burn (Sun Protection Factor). European Journal of Molecular \& Clinical Medicine 8(1): 417-423.

Athayde ML, Taketa ATC, Gosmann G \& Schenkel EP. 2017. Saponinas. In Farmacognosia: do produto natural ao medicamento (Simões CMO, Schenkel EP, Mello JCP, Mentz LA \& Petrovick PR, orgs.). Porto Alegre: Artmed. pp. 285-303.

Bayer C \& Mielniczuk J. 2008. Dinâmica e função da materia orgânica. In Fundamentos da matéria orgânica do solo: ecosistemas tropicais e subtropicais (Santos GA, Silva LS, Canellas LP \& Camargo FAO, eds.). 2ed. Porto Alegre: Metrópole. pp. 7-18.

Boene HCAM, Nogueira AC, Sousa NJ, Kratz D \& Souza PVD. 2013. Efeitos de diferentes substratos na produção de mudas de Sebastiania commersoniana. Revista Floresta 43(3): 407-420. http://dx.doi. org/10.5380/rf.v43i3.25789

Ministério da Agricultura, Pecuária e Abastecimento (MAPA). 2010. Manual de hortaliças não convencionais. Brasília: Mapa/ACS.

Campos RAS, Lima GPP, Seabra Júnior S, Takata WHS \& Silva EG. 2012. Crescimento e desempenho de bertalha (Basella alba L.) em função do tipo de propagação. Revista Caatinga 25(4): 11-18. http:// hdl.handle.net/11449/19112

Chalker-Scott L \& Fuchigami LH. 2018. The role of phenolic compounds in plant stress responses. In Low temperature stress physiology in crops ( $\mathrm{Li} \mathrm{PH,} \mathrm{ed.).}$ CRC Press, pp. 67-80.

Costa JPV, Barros NF, Albuquerque AW, G. Moura Filho $G$ \& Santos JR. 2006. Fluxo difusivo de fósforo em função de doses e da umidade do solo. Revista Brasileira de Engenharia Agrícola e Ambiental 10(4): 828-835. http://dx.doi.org/10.1590/S1415-43662006 $\underline{000400007}$

CPTEC-INPE. Centro de Previsão de Tempo e Estudos Climáticos - Instituto Nacional de Pesquisas Espaciais. 2018. Arquivos do Laboratório de Meteorologia e Climatologia, vinculados ao CPTEC-INPE. Campo Grande - MS.

Czelusniak KE, Brocco A, Pereira DF \& Freitas GBL. 2012. Farmacobotânica, fitoquímica e farmacologia do Guaco: revisão considerando Mikania glomerata Sprengel e Mikania laevigata Schulyz Bip. ex Baker. Revista Brasileira de Plantas Medicinais 14(2): 400409. https://doi.org/10.1590/S1516-0572201200020 0022

Deshmukh SA \& Gaikwad DK. 2014. A review of the taxonomy, ethnobotany, phytochemistry, and pharmacology of Basella alba (Basellaceae). Journal of Applied Pharmaceutical Science 4(1): 153-165. https:// doi.org/10.7324/JAPS.2014.40125

Fernandes MS, Souza SR \& Santos LA, eds. 2018. Nutrição mineral de plantas. Viçosa: SBCS.

Fontoura FM, Matias R, Ludwig J, Oliveira AKM, Bono JAM, Martins PFRB, ... Guedes NMR. 2015. Seasonal effects and antifungal activity from bark chemical constituents of Sterculia apetala (Malvaceae) at Pantanal of Miranda, Mato Grosso do Sul, Brazil. Acta Amazonica 45(3): 283-292. https://doi.org/10. 1590/1809-4392201500011

Gobbo-Neto L \& Lopes NP. 2007. Plantas medicinais: 
fatores de influência no conteúdo de metabólitos secundários. Química Nova 30(2): 374-381. https://doi. org/10.1590/S0100-40422007000200026

INMET. Instituto Nacional de Meteorologia. Estações Automáticas-Gráficos-Precipitação 3m. 2018. Available in http://www.inmet.gov.br/portal/index.php? $\underline{r}=$ home/page\&page=rede_estacoes_auto_graf (accessed on 27-X-2019).

Jayswal VB, Patel VH \& Dave NR. 2019. Effect of incorporation of fresh Basella alba leaves on sensory attributes and antioxidant potential of a traditional indian product 'Biwadi'. International Journal of Pure \& Applied Bioscience 7(1): 425-434. http://dx.doi.org/ 10.18782/2320-7051.7382

Kämpf AN. Substrato. 2005. In Produção comercial de plantas ornamentais (Kämpf AN, ed.). Guaíba: Agrolivros. pp. 45-72.

Khare CP. 2012. Indian medicinal plants: an illustrated dictionary. Calcutta: Springer Science Business Media.

King A \& Young G. 1999. Characteristics and occurrence of phenolic phytochemicals. Journal of the American Dietetic Association 99(2): 213-218. https://doi.org/ 10.1016/S0002-8223(99)00051-6

Kinupp VF \& Lorenzi H. 2014. Plantas alimentícias não convencionais (PANC) no Brasil: guia de identificação, aspectos nutricionais e receitas ilustradas. Nova Odessa: Instituto Plantarum de Estudos da Flora.

Kortbeek RWJ, Van Der Gradt M \& Bleeker PM. (2019). Endogenous plant metabolites against insects. European Journal of Plant Pathology 154(1): 67-90. https://doi.org/10.1007/s10658-018-1540-6

Kumar BR, Anupam A, Manchikanti P, Rameshbabu AP, Dasgupta \& Dhara S. 2018. Identification and characterization of bioactive phenolic constituents, antiproliferative, and anti-angiogenic activity of stem extracts of Basella alba and rubra. Journal of Food Science and Technology 55(5): 1675-1684. https://doi. org/10.1007/s13197-018-3079-0

Lattanzio V. 2013. Phenolic compounds: Introduction. In Natural products: Phytochemistry, botany and metabolism of alkaloids, phenolics and terpenes (Ramawat K \& Mérillon JM, eds). Switzerland: Springer Nature, pp. 1543-1580.

Matos FJA. 2009. Introdução a fitoquímica experimental. 3ed. Fortaleza: Edições UFC.

Meira MR, Cabacinha CD, Figueiredo LS \& Martins ER. 2013. Barbatimão: ecologia, produção de tanino e potencial socioeconômico na região norte mineira. Enciclopédia Biosfera 9(16): 466-494.

Minatel DG, Pereira AMS, Chiaratti TM, Pasqualin L, Oliveira JCN, Couto LB, ... Franca SC. 2010. Estudo clínico para validação da eficácia de pomada contendo barbatimão (Stryphnodendron adstringens (Mart.) Coville)* na cicatrização de úlceras de decúbito. Revista Brasileira de Medicina 67(7): 250256.

Morais LAS. 2009. Influência dos fatores abióticos na composição química dos óleos essenciais. Horticultura Brasileira 27(2): 4050-4063. Available in https:// ainfo.cnptia.embrapa.br/digital/bitstream/item/14345 7/1/2009AA-051.pdf (accessed on 27-X-2019).
Oliveira AKM, Ribeiro JWF, Fontoura FM \& Matias R. 2013. Leaf extract effects of Vochysia divergens on lettuce and tomato. Allelopathy Journal 31(1): 129138. Available in http://www.seer.ufu.br/index.php/ biosciencejournal/article/download/29614/17756/0 (accessed on 27-X-2019).

Passos RR, Ruiz HA, Mendonça ES, Cantarutti RB \& Souza AP. 2007. Substâncias húmicas, atividade microbiana e carbono orgânico lábil em agregados de um Latossolo vermelho distrófico sob duas coberturas vegetais. Revista Brasileira de Ciência do Solo 31(5): 1119-1129. https://doi.org/10.1590/S0100-068 $\underline{32007000500027}$

Peixoto Sobrinho TJS, Silva CHTP, Nascimento JE, Monteiro JM, Albuquerque UP \& Amorim ELC. 2008. Validação de metodologia espectrofotométrica para quantificação dos flavonoides de Bauhinia cheilantha (Bongard) Steudel. Revista Brasileira de Ciências Farmacêuticas 44(4): 683-689. http://dx.doi.org/ 10.1590/S1516-93322008000400015

Pina JC, Oliveira AKM, Matias R \& Silva F. 2018. Influência de diferentes substratos na produção de fitoconstituintes de Moringa oleifera Lam. cultivada a pleno sol. Ciência Florestal 28(3): 1076-1087. http:// dx.doi.org/10.5902/1980509833394

Primavesi AM. 2017. Manejo ecológico do solo: a agricultura em regiões tropicais. São Paulo: Nobel.

Ramprasath VR \& Awad AB. 2015. Role of phytosterols in cancer prevention and treatment. Journal of AOAC International 98(3): 735-738. http://dx.doi.org/ 10.5740/jaoacint.SGERamprasath

Revathi D \& Sudha N. 2018. Phytochemical evaluation of Basella alba L. EPRA International Journal of Research and Development 3(8): 81-85. Available in http://eprajournals.com/jpanel/upload/750am 11.Re vathi,\%20D-2533-1.pdf (accessed on 27-X-2019).

Robbers JE, Speedie MK \& Tyler VE. 2007. Farmacognosia e farmacobiotecnologia. São Paulo: Editora Premier.

Simões CMO, Schenkel EP, Mello JCP, Mentz LA \& Petrovick PR, orgs. 2017. Farmacognosia: do produto natural ao medicamento. Porto Alegre: Artmed.

Santos DH, Silva MA, Tiritan CS, Foloni JSS \& Echer FR. 2011. Qualidade tecnológica da cana-de-açúcar sob adubação com torta de filtro enriquecida com fosfato solúvel. Revista Brasileira de Engenharia Agrícola e Ambiental 15(5): 443-449. https://doi.org/ 10.1590/S1415-43662011000500002

Sousa CMM, Silva HR, Vieira Júnior GM, Ayres MCC, Costa CLS, Araújo DS, .. \& \& Chaves MH. 2007. Fenóis totais e atividade antioxidante de cinco plantas medicinais. Química Nova 30(2): 351-355. http:// dx.doi.org/10.1590/S0100-40422007000200021

Suganthi A \& Tamilarasi A. 2015. Comparative studies on phytochemical analysis of Basella alba (L.) varieties. World Journal of Pharmacy and Pharmaceutical Sciences 4(10): 1089-1098. Available in https://storage.googleapis.com/journal-uploads/wjpp s/article issue/1443606661.pdf (accessed on 27-X2019).

Teixeira PC, Dogagema GK, Fontana A \& Teixeira WG, eds. 2017. Manual de métodos de análise de solo. Brasília: Embrapa Solos. 
Tongco JVV, Añis AD \& Tamayo JP. 2015. Nutritional analysis, phytochemical screening, and total phenolic content of Basella alba leaves from the Philippines. International Journal of Pharmacognosy and Phytochemical Research 7(5): 1031-1033.

Yen GC, Chen HY \& Peng HH. 2001. Evaluation of the cytotoxicity, mutagenicity and antimutagenicity of emerging edible plants. Food and Chemical Toxicology 39(11): 1045-1053. https://doi.org/10.1016/S02 78-6915(01)00053-9

Ye WC, Zhang QW, Liu X, Che CT \& Zhao SX. 2000. Oleanane saponins from Gymnema sylvestre. Phytochemistry 53(8): 893-899. https://doi.org/10.1016/ $\underline{\text { S0031-9422(99)00483-5 }}$ 